\title{
Disability Humour in English Jestbooks of the Sixteenth and Seventeenth Centuries
}

\section{Korhonen, Anu}

2014

Korhonen , A 2014 , ' Disability Humour in English Jestbooks of the Sixteenth and

Seventeenth Centuries ' , Cultural History , vol. 3 , no. 1 , pp. 27-53 . https://doi.org/10.3366/cult.2014.0053

http://hdl.handle.net/10138/153929

https://doi.org/10.3366/cult.2014.0053

publishedVersion

Downloaded from Helda, University of Helsinki institutional repository.

This is an electronic reprint of the original article.

This reprint may differ from the original in pagination and typographic detail.

Please cite the original version. 


\title{
Disability Humour in English Jestbooks of the Sixteenth and Seventeenth Centuries
}

\author{
Anu Korhonen, University of Helsinki
}

If we define culture as a set of tools for making sense of the world, and all the ways in which those tools are used, then 'culture, the great enabler, is also disabling'. ${ }^{1}$ Let me quote this well-known suggestion by Ray McDermott and Hervé Varenne at more length. If culture teaches us all we know and the ways it can be known, it always also gives us 'a blind side, a deaf ear, a learning problem, and a physical handicap. For every skill that people gain, there is another that is not developed; for every focus of attention, something is passed by; for every specialty, a corresponding lack. ${ }^{2}$ Culture invents 'disabilities' for us. The meanings of bodily normalcy and deviancy are defined against each other, and the practices that classify and control bodily lacks are constructed within culture.

In this article, the cultural work that constructs disability takes the form of humour. I look at how disability was represented in sixteenthand seventeenth-century English jestbooks and reflect on what these jokes suggest about early modern society and its disabilities more generally. ${ }^{3}$ It would be easy to see comic portrayals of disability only as a history of victimization, but although there is no denying that discrimination against disabled people was widespread, I want to argue for a more complex view into the workings of comic disability. However conservatively framed, humour always suggests an ambiguity, a possibility of interpretation on various levels that remains unstable regardless of the joker's intentions. Disabled people were consistently presented as objects of ridicule in early modern humour, but underneath the jokes' surface, more can be detected than just cruelty and callousness. It would be too much to suggest that

Cultural History 3.1 (2014): 27-53

DOI: $10.3366 /$ cult.2014.0053

(C) Edinburgh University Press www.euppublishing.com/cult 
disability itself was given a voice in such humour, but even when disability remained an Other for the normalizing thrust of humour, the processes of normalization were dependent on what it defined as a lack. Culturally speaking, disability was open to interpretation.

As Tom Shakespeare has suggested, visible impairments are among the key comic objects of stereotypes in Western culture. ${ }^{4}$ Physical difference worked as a humorous device in sixteenth- and seventeenthcentury jestbooks just as it does in everyday life today. Analyses of the relationship between disability and humour are still rare, although these questions have been cropping up more frequently in recent examinations of disability in contemporary popular culture, particularly in stand-up and television comedy. ${ }^{5}$ In the sixteenth century, jestbooks were a new genre that served much the same purpose as comic entertainment today. The first English-language jestbook, A Hundred Merry Tales, first published in 1526 and probably collected from oral sources, already contained disability jokes. ${ }^{6}$ Collections of jokes and short funny anecdotes were published irregularly through the sixteenth and seventeenth centuries, with recurring bursts of interest in collecting, translating, plagiarizing and publishing. Like most early modern English publications, jestbooks were mostly produced in London, and they often reflect a vaguely urban setting but present a wide variety of characters.

Although disability in its various guises was present in jestbook humour from the very start, it was not necessarily a specific concern for jest collectors and readers. They did not deliberately set out to collect jokes about disabled people, nor did they always see disability as a unified comic class. Rather, the presence of disability in early modern humour reflects the presence of disabilities in society at that time: people joked about what they saw. But disability humour also reflects an early modern 'sense of humour', although the concept had not yet been invented. Before the eighteenth century, laughter theorists suggested that laughter arose primarily from the perception of something ugly or deformed and secondarily from something surprising. Sixteenth- and seventeenth-century laughers struggled with the moral and political implications of this view. ${ }^{7}$ The deviant bodies and capabilities of disabled people were inherently laughable, so they were considered both natural instigators of laughter and targets of ridicule. In this way, humour buttressed processes of labelling people with impairments as 'disabled' even when a clear-cut category of disability did not exist, while also reinforcing the idea of able-bodied identities as normative. Yet mocking the unfortunate was never quite appropriate. As Rosemarie Garland-Thomson has shown, the disabled 


\section{Disability Humour in English Jestbooks}

body became 'a repository for social anxieties about such troubling concerns as vulnerability, control, and identity'.

Disability jokes were not just about bodily difference, then. They were about performing the cultural rules which governed the form of ideal bodies. They also demonstrated the cultural processes that assigned disabled people an inferior social position. ${ }^{9}$ Telling, collecting and publishing disability jokes reinforced these performances and processes; jesting was thus a form of cultural work. While anxieties about bodily vulnerability and the physical restrictions of disabled life were being negotiated, jokes also took part in constructing categories of disability, with their various cultural meanings, as possible markers for individual identities. When anxieties were turned into comedy, different categories of disabilities were endowed with different comic qualities and processes. Humour showed that laughter was one appropriate reaction to disability, and it illustrated what the possible reasons for this interpretation were. Thus the disabled body was made to carry a comic meaning which in turn could qualify social power relations. If disabled people could be treated as comic spectacles, their plight did not have to invite more serious consideration.

In early modern culture, however, the disabled jester's involuntary position was also curiously valued. This can be seen especially well in the case of fools, many of whom could be classified as cognitively, and sometimes also physically, disabled. Physically and mentally anomalous people who were willing and able to turn their disability into comedy were sought after as prized belongings, and the laughter they incited was seen as useful for their spectators' mental and physical health. In special cases, then, disability's relationship with humour could provide a way of earning a living or securing care ${ }^{10}$ Even if this did not apply to most disabled people, the Renaissance comic vision always carried a paradoxical question of cultural value.

Here a caveat is in order, however. One cannot read jests as straightforward reflections of early modern attitudes towards disability, any more than one would read them as unproblematic indications of social reality. Humour is much more complicated than that. It often focuses on cultural rifts and tensions, but it simplifies what is at stake. Humour can present both the normal and the abnormal as ridiculous, and it can side with both the mighty and the oppressed. It plays on the cultural boundaries between the licit and the illicit, but in the case of early modern jesting, it is not always clear on which side of this distinction the joker stands. Disability marked one such boundary in the sixteenth and seventeenth centuries; otherwise, it would not figure 
so prominently in jestbook humour. But when the jests of this period represent disability, is it an expression of cruelty and disparagement, or does it refer to something more complicated? Just by reading these jests, we cannot get at the fundamental meaning a joke may have had when told in a social situation: its meanings would have changed according to who was present, how the joke was told, what its discursive and social contexts were and, most important, how its listeners decided to react to it.

Printed jokes were mostly socially conservative, and their treatment of disability, too, tended to reinforce negative stereotypes rather than interrogate discursive truths. Still, the place of disability and disabled people in jestbook humour is more complex than might be imagined from the outset, and a close reading of jokes reveals a greater variety in understandings of disability than we might think was typical of early modern culture. Let us now look at these negotiations in more detail.

\section{A History of the Senses}

The best-known basis for an early modern conceptualization of disability comes from legislation on poverty, which separated the able-bodied from those deserving of institutional assistance. Begging was allowed only for those who were not able-bodied, at least in theory. The English Poor Laws of the late sixteenth century sought to guarantee that the ill and the injured, orphaned children and elderly people, and those who were physically or cognitively impaired would get poor relief from parishes, other religious bodies or towns, although most disabled people were still supported more informally by families and neighbours. ${ }^{11}$ While early modern networks of care were flexible and varied, they all contributed to distinguishing those worthy of support from those who could be expected to look after themselves. In this process, different forms of disability, too, were negotiated and defined.

Disability was constituted partly by the practical need for care that some kinds of impairment suggested but also by the discursive work performed within the various genres of text and speech that discussed disability. Humour was among these genres. The practical applications of institutions' more formal disability criteria were constantly influenced by informal ways of imagining disability and its effect on disabled people's lives. These imaginings can cast more nuanced light on early modern ways of understanding disability.

Jests about disability seem to suggest that problems in sensory perception were considered more disabling than were other physical impairments. There are many more jests about blindness and deafness 


\section{Disability Humour in English Jestbooks}

than there are about the experience of cripples, for example. ${ }^{12}$ Why were sensory disabilities more interesting to early modern jokers than other impairments? This may be partly due to the comic potential of sensory impairments, but it may also be linked to other cultural perceptions of the senses.

The frequency of blindness and deafness jokes is suggestive of the place the senses were awarded in early modern conceptions of knowledge. Sight and hearing were the senses that were most central to acquiring information and understanding the world, and problems with either were thought to damage severely a person's ability to function in the world. ${ }^{13}$ Sight was especially central to early modern conceptions of sense experience and sensory hierarchy. Eyes were the organs that most effectively brought information from the outside world and allowed human beings to orient themselves in their surroundings, perform tasks necessary for staying alive and acquire the knowledge needed for social existence. If visually impaired people were not just figures of fun, they were enough of a comic class to be awarded a section title of their own in many jestbooks, such as the 'Mery jestes of blinde Folkes' in Thomas Twyne's comic miscellanea The Schoolemaster and 'Of Blindnes' in Anthony Copley's Wits Fittes and Fancies. ${ }^{14}$

The more interesting question, of course, is what kind of cultural work blindness and deafness perform in early modern humour. Although jests were meant to entertain, they can also allow us a glimpse into how disability was understood in practice. What did people think blindness felt like? Several jests made fun of blind people's need for light - or of other people's thinking they would benefit from extra light. ${ }^{15}$ Blindness was imagined as perpetual darkness. This was also understood as the 'correct' way to relate to a blind person's world, and jests presented people who thought light could alleviate this darkness as ridiculous.

In a world where artificial light was much less common than in ours, and where the available artificial light was provided only by candles and fires, everybody was much more exposed to darkness than we are now. Everybody needed to be able to function and perform certain tasks in relative darkness - walk down the stairs, find a close-stool or visit a neighbour. This also affected how people envisioned the role of the senses in their everyday lives and when, how and what senses were essential in different situations. ${ }^{16}$ Sight itself had a different scope in everyday life - but rather than making vision less central in the early modern symbolic universe, frequent experiences of darkness heightened the importance of seeing as a basic symbol of survival 


\section{Cultural History}

and knowledge. Where one might expect a positive evaluation of touch and hearing, for example, jokes focused on sight and its absence. Blindness was a useful topic for jesting because it allowed play with the tangled meanings of vision and knowledge. Unlike the scholarly discussion about the uncertainties of vision, brilliantly examined by Stuart Clark, ${ }^{17}$ however, jests were usually content to link sight to wisdom and point towards blindness as a symbol of ignorance and powerlessness.

When we turn from sighted people's prejudices and misunderstandings to comic portrayals of blind people themselves, however, the stress on ignorance dissolves into a much more practical set of problems. Many blindness jokes were situated in everyday surroundings, where the ability to walk up or down stairs, along streets or to the church or nearby houses was a standard requirement. It is these ordinary tasks that reveal how the practical consequences of blindness were understood. Here, blindness did not primarily keep one away from the higher realms of knowledge; its location was in the everyday, particularly in the context of work.

Sometimes, though, that everyday work was made possible only by being able to read, as in the case of the partially sighted parson who after a late night in merry company came to work on a Sunday morning a little the worse for wear and failed to concentrate his eyes on the text from Exodus. Instead of 'And God told Moses', he proclaimed to his congregation 'And God told Noses, \&c' - enough of a joke to be published in Mirth in Abundance. ${ }^{18}$ Perhaps the most typical use of disability in early modern humour was to poke fun at those lacking skills and abilities, as implied by different classes of impairment. Often this resulted in knockabout comedy where vivid physical effects were sought after. Visual impairments caused practical difficulties and errors of judgement:

A purblind fellow in a misty day passing Pauls chaine ran against one of the posts, and taking it for a man said, I cry you merry [sic] Sir, and presently running against the other, said, I cry you mercy againe Sir, truly I thinke you and I shall meet in Heaven. ${ }^{19}$

Here the purblind or partially sighted man is the only character we see, but his imagination conjures up a comic companion, more or less indispensable in the jokes of the time. The blind man here invites laughter by both his actions and his interpretation of them, but in fact disabled people were more commonly tricked into trouble by other characters. Blind people were led into situations where their inability 


\section{Disability Humour in English Jestbooks}

to see was exploited; deaf people got in trouble for not hearing. In these jokes, the disabled characters were used and abused by other characters for comic purposes that, to a modern reader, often seem not all that humorous.

Like Simon Dickie in his study of eighteenth-century jestbook humour, one has to wonder about the callousness and cruelty of these jests. ${ }^{20}$ It is difficult to find any other explanation for them except simple delight in other people's misery - a self-congratulatory feeling of one's superiority in the face of others' vulnerability and helplessness. This would indeed go well with one of the strands of early modern humour theory. Thomas Hobbes, for example, famously attributed laughter to the 'sudden glory' produced by an 'apprehension of some deformed thing in another, by comparison whereof [the laughers] suddenly applaud themselves'. ${ }^{21}$

If we take this claim seriously, jests do not just display random cruelty but are evidence of an ideology which "necessarily dismissed the deformed or the disabled as foreign, transgressive, ugly and inherently worthy of contempt', as Roger Lund has suggested. ${ }^{22}$ While I would not reject this idea outright, it might be somewhat qualified by remembering the complex and contextually knotty nature of humour. Feelings of superiority are certainly much in evidence in disability humour, but early modern theories of humour also specifically proposed that laughter demanded a deliberate rejection of pity, even when pity would have been a natural reaction to the same spectacle in serious contexts. George Puttenham in his study of rhetoric, for example, placed pity and ridicule as alternative reactions in the face of ugliness and indecency. ${ }^{23}$ In early modern laughter theory, the cultural scope of ugliness was wider than just a perceived physical quality. Laurent Joubert, for one, lists many varieties of comic deformity that would hardly be classed as ugliness today. ${ }^{24}$ In practice, then, humour may have represented a mechanism of bypassing sympathy and empathy, of distancing the object into the sphere of the laughable when confronting it on a more sensitive plane was difficult to handle.

Jokes were an arena for testing and developing this approach to disability. They taught laughers to encounter disability without pity, rendering disabled people inferior objects instead of feeling subjects. It is hard to see what else could be funny about Twyne's joke describing a theft, for example. In the following jest, a blind husband's plight may have plucked at the heartstrings of a sensitive reader, but according to laughter theory, the comic elements in the story should have prevented him from being pitied. If the joke was retold by the reader, as such jests 


\section{Cultural History}

were supposed to be used, much must have depended on how the last line was delivered:

A blind man and his wife had a fat goose to dinner, and while the wife was gone forth about business, and the blind man turned the spit, there came a good Fellowe into the howse, which hee hearing and thinking it to be a dog, rose up to ratle the dishes to driue him away. In the meane whiles this fellow stole awaye the goose, and put a great browne loafe which stood there by vpon the spit, and departed, and he turned the loafe about very diligently: but when the good wife came in, hee chid her sharply for leauing the dore open, for sayd he, there came in a dog euen nowe, and had I not moued the dishes to driue him awaye, hee would haue done some harme. O Husband said she, it was no dog, but some theefe, and he hath stolen away the goose. ${ }^{25}$

None of the characters does or says anything very funny - unless we count a married man engaged in wifely duties as funny in itself. The point of the joke is not gender inversion, of course, even though early modern jestbooks joked about gender relentlessly; instead, laughter is supposed to be raised by the ease of deceiving a blind man. Yet gender is central to this joke as well. A grown man engaged in household chores would have seemed funny to many early modern readers, but it is his inability to succeed even in turning the spit that exposes his vulnerability. The joke suggests that it was impossible for a blind man to function effectively as the head of a household.

\section{Masculinity and Disability}

Blindness may have forced an early modern husband to betray the patriarchal ideal and submit to the humiliation of turning the spit while his wife went out on business, but disability posed the question of control in other ways, too. The problem of disabled men falling short of ideals of both masculinity and patriarchy is also evident in a cuckoldry joke involving a partially sighted husband, published in Copley's Wits Fittes and Fancies. As in so many jokes about cuckoldry, the one-eyed husband enters his bedchamber, where his wife is in bed with another. Before the husband can make sense of what is happening, his resourceful wife tells him of a happy dream of hers, in which he had got his sight back, and asks whether she could put her finger on his seeing eye to check if a miracle had indeed happened. With her finger on his eye, the husband sees nothing, but the lover successfully escapes the room. ${ }^{26}$ More than his impairment, the husband's fault was being too gullible to maintain control of his wife and her behaviour, particularly her sexuality. Even though it was the husband's blindness 


\section{Disability Humour in English Jestbooks}

that generated the comedy, the jest invokes the same themes and scenes that made the genre of cuckoldry jokes extremely popular. Blindness was only an added component to make deception possible.

Patriarchal masculinity entailed an ideal of independence that disability humour brought into question. Disabled men were at the mercy of their wayward wives, but they were also taken advantage of by their cunning servants. Many jokes show blind people retaining a companion or servant to help them move about, and usually that servant is described as a boy. One such boy saw his master's disability as a chance to feast on unlawfully appropriated meat: in a house where the pair had gone begging, the blind master was given both boiled and roasted meat. The boy gave his master only the boiled variety and ate the roast himself. By and by the master smelled a rat, or perhaps a roast, and confronted his servant. The brazen boy did not repent but led his master away and even purposely walked him against a whipping post, so that the poor man 'hits his face a very sore knock', as if taking the meat was not enough of a practical joke. ${ }^{27}$

This was certainly not a response recommended in polite discourse. Instead, disability, although a sign of diminished masculinity, was supposed to be treated with patience and tolerance. The Duchess of Cavendish, for example, attributed old men's perceived habit of talking too much to their loss of hearing: if it was too strenuous to try to listen to other people's stories, one tended to compensate by telling one's own and easily started to babble too much. ${ }^{28}$ Accounting for old men's faults by referring to their disability was a way of making the behaviour more excusable - it was a minor handicap brought by age rather than a character flaw. This does not give elderly men back the authority they lost when growing old and deaf, but it made them look less foolish. Even if the Duchess of Cavendish was hardly an average early modern thinker, her view of deafness and, by extension, of disability was relatively typical. It is this lenient understanding that jestbooks knowingly challenged.

Disability jokes were not just about knowledge, then, but about power. Disability left the characters of these jokes at the mercy of their seeing companions, be they wives, servants or neighbours. The gender of the protagonists of blindness jokes reveals an interesting divide: while there are several jokes about deaf women, blind figures in early modern humour are almost exclusively men. The trouble with disability seems to be the resulting inability of the male characters to control those supposedly underneath them according to the rules of patriarchy. The comedy of these jokes often comes from a reversal of the social hierarchy. It is typical of jokes of the time in general that 
those supposedly in power find themselves in an inverse position. Disabled characters are not an exception in this sense. Disability was not, then, only a contrary image to an ideal masculinity that favoured physical strength and sexual prowess but an antithesis of patriarchy and its gradations of power. The ideal patriarch was economically independent, adult, physically strong and able-bodied, but patriarchy's upkeep also demanded attention to those who fell short of this ideal. Humour about male disability negotiated social power by making fun of those whose impairments would have called patriarchy into question.

Often this was done by juxtaposing able-bodied (but not always intellectually top-notch) characters with disabled figures in ways that now may seem quite cruel. A striking example is a joke where two men pass 'a dumbe man' begging in the street in 'his mute manner' and feel offended by his interruption of their conversation. One of the men berates the disabled person and lifts his foot to kick him, but the other holds him back: 'O fie - will you kick a dumbe man?' 'Is hee dumbe', realizes the first man, and wonders, "why did he not tell me so then? ${ }^{29}$ On the face of it, of course, the joke presents a humane view: one should not kick a mute beggar on the street. But how far does this humanity extend? Apparently, kicking annoying beggars would be less problematic if they were not disabled. Even if the object of ridicule here seems to be the aggressive gentleman, the disabled person is not allowed much humanity; he is merely the object of other people's charity, or their pity, a poor beggar who has no place in society. This is also why he can be used as a prop in a joke, without individuality, reduced only to his impairment. Still, it is worth mentioning that an aborted kick hardly even counts as violence within the context of early modern humour. Jokes sometimes depicted extreme violence. In the most excessive portrayals of brutality, disability does not figure - not even as a result of the aggression. Comic violence tends not to leave physical marks.

Jestbook figures who would have been considered to be deformed in early modern discourse were also often male. Although crippled and deformed women certainly existed, they play a very minor part in jests, as well as in visual images such as Pieter Bruegel's famous drawings and paintings. ${ }^{30}$ English jestbooks mention some female dwarfs but otherwise are not much interested in female beggars or women's deformities. This is perhaps surprising considering the insistence that laughter arose from ugliness; apparently, not all ugliness was equally laughable or equally suited to different genres of comic literature. Jestbooks were more concerned with disability as a joking matter than 


\section{Disability Humour in English Jestbooks}

with its actual manifestations, and disability figured more as a constituent of power relations than as an accurate depiction of early modern society.

A joke, this time of French origin, that partly reproduces the situation of the beggar-kicking jest above may illustrate this point. Several courtiers passing a bridge in Paris see a blind beggar whom they suspect to be a counterfeit. A duke who is basely born and has the manners to match wants to prove the beggar's deception and puts him to the test. He tells his companions that if the beggar can see, he will certainly recognize the duke, who passed him by daily. So the duke goes and pulls the beggar by the nose, and the beggar roars out, calling him a 'bastardly rogue'. For the duke, this is proof of the beggar's ability to see; how else would he have known the duke so well? This would surely have been enough for an early modern reader to get the joke, but the jestbook compiler felt it necessary to add an extra explanation that is useful for our purposes here: the beggar was indeed blind, and what he said was "only a vicious speech often in his mouth'. ${ }^{31}$ Even though the beggar was certifiably blind and the courtier aggressively pulled his unsuspecting nose, the beggar's protestations were counted as 'vicious speech' that said more about his character than the courtier's actions. Yet it is the base-born courtier who is the real butt of humour in this joke. More important, by proving the beggar's disability he also proved his own bad manners and acknowledged his merits as a bastard and a rogue. Although we might want to stop at seeing how natural it is for the jest's courtly characters to abuse the blind beggar, reading the joke in context also invites reflection on how disability worked towards revealing and defining status differences.

\section{Disabled Women and Sexuality}

If disabled men were useful to allow early modern humour to discuss power and status, disabled women appeared in a different light. They were most often discussed as an illustration of general female failings or in the context of sexuality and marriage. These jokes often referred to the familiar comic stereotypes about women as loquacious and quarrelsome, for example. ${ }^{32}$ Disabled women could be suggested as a convenient wifely option: someone being asked why he meant to marry a deaf woman answered that he hoped she was also 'dumb', or mute. ${ }^{33}$ It would be easy to argue that this joke was mostly not about disability; it was about women and their nature in general.

One of the most often repeated of all early modern jokes also played with the question of women and muteness. Wishing to cure a rich and 
beautiful wife who could not speak, a compassionate husband went to a specialist for help, in some versions turning to a doctor, in others to the Devil himself. The professional suggested a remedy: the husband was to place an aspen leaf under his wife's tongue when she was asleep. The eager husband popped several aspen leaves into his wife's mouth, and sure enough she started to speak, but in the stereotypical manner of all wives, she soon began to babble and boss her husband relentlessly. When the worn-out husband revisited the authority to ask how he could make her quiet again, he was told that while it was entirely possible to make a woman speak, once they had started talking, not even the Devil could shut them up. ${ }^{34}$ Again, muteness was a way to criticize all women, not disabled women in particular - in fact, the masculine irony of jestbooks suggested that the disabling of women corresponded to the enabling of men. Early modern society was well aware of the power of ridicule as social control, ${ }^{35}$ and women were the most commonly ridiculed group of people. Seen as inherently humorous because of their gender, they were also considered the group most in need of mocking, partly in the hope that mockery might correct their faults and partly as a safeguard for male honour, which always seemed to be threatened by women's rebelliousness.

It is important to note, however, that the humorous world of the jestbook does not necessarily represent the views of all men but rather, as Tim Reinke-Williams has suggested, expresses a subculture of youthful urban misogyny. According to Reinke-Williams, many jokes may have had their origins in the banter of adolescent jokesters, often apprentices who were themselves subordinated by patriarchal institutions and who channelled their rebellion not so much against authority as against the other significant subordinated group, women. $^{36}$ But whoever the jestbook authors and readers were, women were clearly a laughing matter. Located in several categories of the humorous at once, disabled women would seem a natural target for scorn, but in fact they were not as purposefully mocked as one would expect. It seems that laughter at female impairments targeted women without disabilities more than those with disabilities.

But it is indicative that when disabled women were laughed at, they were routinely ridiculed by sexual joking, not just because of their impairment, its social consequences or their inherently laughable womanhood. $^{37}$ That disability was easily linked with sexuality in humour comes as no surprise: in his study of disability in the ancient world Robert Garland found that humour targeting the disabled was often 'fuelled by sadistic, sexual and scatological impulses'. 38 


\section{Disability Humour in English Jestbooks}

In the early modern period this seems to be especially true of disabled women, whereas sexuality plays only a moderate role in jokes about disabled men. ${ }^{39}$

If the most favoured male disability within jestbook humour was blindness, most disabled women were portrayed as deaf. This has much to do with the sexual context of jests. Although blind people, whether men or women, were not excluded from the sphere of sexuality, disability affected the way in which blind women's desire was conceptualized - or not conceptualized. Relating somewhat paradoxically to the idea that love and desire were aroused by beauty, blind men in jestbooks stressed their wish to have beautiful women for wives. Blind women's desires are mostly absent from early modern humour. More important, the relationship between beauty and desire may have influenced how disabled women were viewed as objects of sexual desire. Blindness made a woman undesirable. Deafness, however, did not affect women's looks and did not render them unacceptable to men looking for sexual pleasure. Women's deafness actually gave the men a perfect opportunity to joke about their sexual intentions, even in company where sexual suggestions to hearing women would have been unacceptable.

In his private collection of jests, Sir Nicholas Le Strange relates a version of a very popular joke about a deaf old woman being toasted at dinner. Despite the frequency with which this joke was recorded in published jestbooks, Le Strange's version provides us with specific protagonists, much local colour and the identity of the joke-teller, 'Ma Mere'. In Le Strange's notes, then, when 'one Mrs Thurlow, extreame Deafe', was invited to dinner at Sir Henry Sidney's house, the host raised a toast to her and declared, 'Here Mrs Thurlow, upon condition you lye with me to Night.' When Mrs Thurlow answers, 'Your worship knows what's good [...] for an Old Woman', Le Strange (or his mother) is careful to point out that Mrs Thurlow only meant the sack - the wine with which she was honoured-and did not respond to the sexual taunt. The narrator also explains how 'all the company taking the sentence entire, and not dismembered, laught heartily at it'. ${ }^{40}$ Even published jestbooks sometimes attached explanatory morals to their tales, but Le Strange's manuscript pays attention to social relations in the jesting situations, sometimes offering observations about how the jests were received. For Le Strange and his mother, Mrs Thurlow's deafness was a joking matter.

But women had no monopoly on representations of disability in sexual contexts, for male disabled figures' sexuality was a source of jokes as well. One wife got back at her one-eyed husband, who accused 
her of having had sex with another before marriage, by claiming that if she had lost her maidenhead, then he was not all that perfect either. ${ }^{41}$ Wedding nights were a special delight for those joking about blind men. In one of these jokes a blind bridegroom kisses his bride under the cover of his own darkness but in full view of everyone else. When the modest bride asks him to wait until they are in bed, the new husband answers, 'Nay (Mouse) all is night with mee. ${ }^{42}$ But perhaps the most graphic, and in some ways the most puzzling, of the early modern sex-related disability jokes involves a man and a woman who are both blind. While many jokes appeared in several versions and seem to refer to a familiar theme, this joke stands alone. A blind man wants to marry quickly, so he asks a friend to find him a wife who is 'endued with all the Perfections her Sex is Capable of'. Instead, the prankster brings him a woman as blind as he is himself, assuring his friend that she is 'as compleat a Woman as ever he saw with his Eyes'. The contented blind man wants to organize a wedding immediately, but because his own house is not yet in order, he asks whether the newly-weds could stay with the friend. The wedding is cheerful and includes liberal drinking at an inn, until the bridegroom calls for the bill, wishing to enjoy his bride in private. Instead of taking the pair to his house, however, the friend prepares a bed for them out by the highway, wishes them much joy and leaves them in open view, in plain daylight, while standing at a distance himself. People begin to gather around the pair, wondering at the sight and talking amongst themselves, but the newly-weds are still blissfully unaware that they are not lying behind closed doors at their friend's house. At length the blind man hears the crowd's chatter, gets up and asks, 'Who's that?' Nobody answers him, so he tells them that 'they were a parcel of base unworthy people - to look in at any Peoples windows'. It is not because he is unable to know the time of day, but because linking blindness to the experience of darkness was so common, that he continues, 'If it were day-light, I would make the best of you all to smart for it'. And so he 'went to Bed again'. 43

Many blindness jokes played with the idea that the disabled are ignorant about their surroundings: the blind cannot tell night from day, do not know where they are, and have no way of knowing what kind of people they are associating with. This says more about the able-bodied imagination, of course, than it does about the everyday experience of the blind. There is little in the wedding-bed joke that would have enlightened its listeners about disability. Rather, it only seems to offer voyeuristic delight by evoking the imagined scene of sexual bliss in open view and in full daylight. The disabled figures are 


\section{Disability Humour in English Jestbooks}

there only for crude fun. In this sense, it is a perfect example of how disability could be exploited for humorous purposes - but, at the same time, we have to remember that the disabled were not the only group exploited like this: young, sexually inexperienced people were habitually made fun of in exactly the same way.

The question we have to consider, then, is whether the representations of disability as forced ignorance within jestbook humour also reflect larger views about disability. In early modern serious discourses, too, the metaphors of both blindness and deafness figure most often in contexts where people are described as willingly ignorant, particularly in connection with religion, or as unable to perceive the glaringly obvious. This discursive context, even though abstract and far removed from the actual world of disabled people, represented disability as a cultural lack, a deficiency that carried a cognitive stigma. In jestbooks we confront a much more practical world of disability. Instead of symbolic uses of categories of disability, we meet people with visual impairments, hearing problems and mobility restrictions who confront challenges in their daily lives. Even if jestbooks portray disability as comic, strangely enough these portrayals are still more positive than the metaphorical meanings routinely associated with disability in serious discourses.

\section{Disabled Agency?}

If many jokes present disabled people either callously as objects of ridicule or as pitiful creatures not in control of their own lives, this is by no means the whole story. In sixteenth- and seventeenth-century jestbooks we can also meet disabled heroes who turn the tables and get back at those trying to deceive or ridicule them.

In some versions of the toasting joke above, for example, the deaf old woman to whom a glass was raised did not remain the sole object of ridicule but succeeded in coming back with an unintentional taunt. In A Banquet of Jests the gentleman's toast goes like this: 'I will drinke to you, and to all your friends, namely the Baudes and Whores in Turnebull street.' The woman whose hearing was impaired, innocently believing she and her family were toasted in a more conventional way, turns the joke on him: 'I thank you Sir, euen with all my heart, I know you remember your Mother, your Aunt, and those good Gentlewomen your sisters. ${ }^{44}$ Even though the deaf woman's answer was not an intended insult, the jest shows that the laughers' anticipated sympathies could just as easily be turned against those who treated disabled people as objects of ridicule. On the other hand, the joker's initial jibe, and what he seems to be expecting in return, again reveals 


\section{Cultural History}

the unthinking objectification with which jestbooks approached disabled people.

Most jokes about deaf people portray characters who have lost their hearing because of an illness or old age. This was a common enough occurrence in a society unfamiliar with modern medical treatments; indeed, early modern people themselves discussed how deafness could be avoided or cured-by guarding against sexually transmitted diseases, refraining from beating schoolchildren excessively and having infants nursed by their own mothers instead of wet nurses, or by inserting in one's ear a black wool cloth dipped in a mixture of mother's milk and betony, for example. ${ }^{45}$ Whatever the reason for one's loss of hearing, before becoming disabled deaf people had often learned to speak, acquired extensive knowledge about everyday matters and adjusted into able-bodied society. In jestbooks deaf people can often be found engaged in activities where hearing was deemed essential-selling various items, for example, although they were always getting in trouble for not being able to answer what their customers were asking. ${ }^{46}$ Many of the comically portrayed deaf people are very skilled about social conventions and manners. Indeed, they are often knowingly tricked into behaving or speaking in an odd way by those who twist good manners to serve their own comic purposes.

Mistakes about manners made deaf people comic, then, but, interestingly, those mistakes also turned their joking partners into comic figures. Familiarity with social mores seems to redeem deaf characters in jokes and give them the possibility to triumph over their opponents. As Emily Cockayne has shown, prelingual deafness, in contrast, was a severe handicap in the early modern period, as most of those born deaf would have remained 'dumb', although not necessarily silent, for their entire lives. ${ }^{47}$ This would have placed them in a more marginal position than those who had been able to hear in their early life. The greater the separation between the deaf person and the hearing society, the less there seems to have been to joke about. As we have seen above, jokes in which muteness appeared either were about total lack of communication, as in the beggar-kicking joke, or were just another formulation of the general perception of female garrulousness, not muteness as such. Most disability jokes, in fact, negotiated social norms rather than dealing with individual people and their various impairments. However, when the deaf were ridiculed as individuals, what often seems to be at issue is their intelligence rather than just their deafness. A tendency to associate speech with understanding was widespread in early modern culture, and, however 


\section{Disability Humour in English Jestbooks}

unfairly, most disabilities were suspected to have cognitive consequences as well. ${ }^{48}$ It is this equation that is questioned in jokes that allow deaf characters to overcome their opponents.

Sometimes jests promoted a view of disabled people as consciously self-assured: their disabilities may have presented them with practical difficulties but did not prevent them from taking part in social, economic and political life. Humour stressed the otherness of those whose disability forced them to survive by begging, but those in a more secure economic position were not presented as incompetent or powerless. In a classical joke included in the anonymously published Gratiae Ludentes, the blind sage Ignatius claims to be content with his blindness because he does not have to see such a tyrant as his opponent, the Roman emperor Julian the Apostate. ${ }^{49}$ Even though the joke worked exactly because the idea of preferring blindness to sight was outrageous, it still presented the disabled person as shrewd and independent, even recklessly courageous.

If one of the recent trends in contemporary disability humour has been the radical negotiation of disability in the performances of disabled comedians themselves, it would be interesting to find hints about disabled people's own jokes in the sixteenth and seventeenth centuries, too. Fool humour sometimes presents us with these possibilities, but with regard to physical and sensory impairments, the joke above is the closest we can get to the use of humour specifically by a disabled person. In the early modern context, the disabled's experience was not often given voice, and we have no access to a look at whether disability could be funny from their perspective. In contemporary culture, disabled people, both comedians and others, tend to make fun of disability to alleviate cultural tensions and anxieties about it and, in more practical situations, to liberate those around them from the weight of empathy. ${ }^{50}$ The blind Ignatius could perhaps be interpreted in this light. In a sense he performed the transformation from tragic into comic that Ian Stronach and Julie Allan describe in their discussion of contemporary disability discourse, achieving several inversions and shifts at once. Ignatius turned his own condition and position from passive to active, from peripheral to central, from disabled to unable and from abnormal to normal. ${ }^{51} \mathrm{By}$ making the emperor look ridiculous, Ignatius took the weight off his own disability and rendered it beneficial. Not only were the tables of social hierarchy turned here, but the blind man, without denying his impairment, made it a tool for his ironic vision. That the joke was of classical origin only enhanced its exemplary power for early modern readers. 
The same tone can also be found in jests that were situated in contexts closer to English readers. It is evident in Twyne's story about a blind man who tried to hide twenty pounds, earned by begging, under a pew in his parish church. A chaplain happened to see him and stole the money. The next morning, not finding his earnings where he left them, the blind man asks his boy to take him to the chancel and see which of the chaplains laughs when he sees the blind man. The blind man then flatters the merry chaplain and promises to tell him a secret: he has hidden twenty pounds under a pew and means to add another twenty later, which he will then donate to the church when he dies, which he expects to happen very soon. The greedy chaplain puts the money back in order to gain a second instalment, but the blind man outwits him. He comes to the church very early, takes his money and leaves the chaplain with nothing. ${ }^{52}$

It is clear, then, that many disabled people were not passive, and jestbooks, despite their tendency to display disparaging attitudes, did not always portray them as such. Rather, disabled characters could be presented as resourcefully overcoming their impairments and, in the process, society's expectations of them. Finding such characters can be tricky, however, because, in their quest for simplicity and a good punchline, jestbooks tended to reduce disabled people to their impairments rather than portray them as well-rounded individuals.

However, jestbooks delight in clever protagonists who outwit their opponents, especially if the latter is a social superior. Thus we encounter a significant number of women getting back at the men who harass them, sly apprentices tricking their masters, parishioners playing practical jokes on their pastors, clever countrymen cozening city dwellers - and disabled people deceiving those who treat them unfairly. Although the disabled were typically objects of ridicule, they could also be identified with as ordinary people who sometimes got the better of their social superiors.

Early modern society was thoroughly hierarchical. Disability was just one factor among many upon which a person's social standing could be based. The ubiquity of different hierarchies made it possible for the able-bodied to identify with the subordinate position of the disabled, even if their own position and experience were different. I do not wish to present a romantic vision of the disabled experience, though: even if some disabled people were presented in a positive light in jestbooks, there is no question that disability also made one an easy target for mocking and jesting. Jestbooks offer ample material to testify to this. 


\section{Disability Humour in English Jestbooks}

\section{Humour and the Category of Disability}

In early modern England, disability was not a clear-cut category, in either a discursive or a practical sense. However, through the frequency with which blindness, deafness and muteness, intellectual and mental impairments, and different kinds of bodily deformities were mirrored against each other and made fun of in the same way, it is possible to see that, at least in a vague sense, jestbooks promoted a view of different disabilities as forming one class. ${ }^{53}$ On a very general level, disabilities represented a flaw in the image of God that the human body was understood to represent. Disabilities equalled deformity; deformity invited laughter.

But this simplification, while it might adequately represent the jestbook view, does not do justice to all early modern thinking about disability. Even if everyday speech and low literature tended to view disability as a set of deviations, some also expressed doubts about whether the human body and its sensory capabilities in fact could apprehend everything there was to the world. Blindness and deafness looked different to the philosophical sceptics, for example. An English text that discussed the sceptical agenda pondered whether a man born blind and deaf but able to touch, smell and taste would have known there was anything to be seen or heard in the first place or would think only the three qualities existed that he could conceive with his senses: 'Even so the apple may have many qualities, but we cannot come to know them because we want fit instruments for that purpose. ${ }^{54}$ Jestbooks had no way of referring to these sophisticated philosophical trends but represented a much more commonplace conception of disability.

Medical and scientific discourses in general were of only minor importance in constructing disability in jestbooks; instead, disability had much to do with work and economic survival, and thus with questions of dependence and independence. For a cultural historian, then, jestbooks necessarily challenge the 'medical model', the traditional modern understanding of disability as a pathology constructed by expert knowledge, particularly by the medical profession. ${ }^{55}$ This links jestbook representations to wider early modern culture. The disability historian Catherine Kudlick has shown how, in the absence of quantifiable tests, blindness was determined by asking a person qualitative questions about his or her ability to perform gendered tasks in society - whether he or she could work in the field or market, sew or look after children, or go to church without help. The same was true of cognitive disabilities, where questions about one's family, one's place of residence and elementary 
arithmetic could determine one's need for care.$^{56}$ Disability was tied to social and economic factors, and the classification of someone as disabled depended on what tasks and knowledge were regarded as culturally important. Humour, although considered rather an insignificant form of cultural intelligence, was one of the discourses in which these categorizations could be worked out, almost without it being noticed. In humour, disability was a social and cultural factor that called attention to the human body and its fragility. It emerges as a lived constraint of everyday life, portrayed as otherness by mostly able-bodied jokers but far removed from later official and scientific understandings. Humour represents a grass-roots level of understanding disability, although its views are not necessarily any more positive than those of the learned or professional experts.

In the sixteenth and seventeenth centuries, disability was not something that touched only a small minority of people. It brought very practical anxieties to many people, who, if they were not impaired at the moment, fully expected to be so in the future. Illnesses, accidents, work, war and famine, together with the process of growing old, produced bodily changes that could be classified as disability. The figures characterized as 'old blind men' and 'old deaf women' in jestbooks, for example, represented otherness because of their advanced age, but they were not necessarily much more disabled than people of their age group were generally considered to be.

Disability was common enough not to raise extreme fear or invite extreme actions. It could be turned into a spectacle when the disabled person did something that was commonly thought impossible or inordinately difficult, however, such as when cripples learned to sew with their mouths or write with their toes. Early modern authors frequently mentioned seeing disabled people perform extraordinary feats and seem to have been very impressed by such wonders and curiosities. The learned naturalist Robert Plot, in The Natural History of Stafford-Shire, describes a blind man called Edward Ingram, who could go to church and walk great distances by himself, make his own shirts, mend shoes, glaze windows, lay floors and do all kinds of joiner's work. ${ }^{57}$ The Dorchester townsman William Whiteway mentioned in 1634 that a Frenchwoman had come to his door who had no hands but could write, sew, wash and do many other things with her feet. ${ }^{58}$ The clergyman John Rous recalled in 1638 how, two years before, he had seen an Italian man with 'shrimped and lame' hands who could handle a needle and thread with his mouth, paint and write in a beautiful 'hand' with both his mouth and his left foot, spin with his 


\section{Disability Humour in English Jestbooks}

mouth, play dice with his feet and even load a 'pretty' gun with his toes, firing it at the same time as another gun that had been put in his mouth. ${ }^{59}$

The writers who had witnessed these marvels described these disabled-yet remarkably able-people with a curious mixture of superiority and admiration: they clearly felt healthy and able-bodied compared to the disabled individuals performing before them, but at the same time they expressed amazement and appreciation. Apart from these wonders, the diarists are silent about encounters with blind, deaf or crippled people. Disability as such was unexceptional; it did not stand out in the flow of everyday life for clergymen, who routinely dealt with issues of charity and poverty, for example. What invited comment was disability with a twist. This, I think, is one context in which we could read disability humour in jestbooks.

Jestbooks used disability because it was a familiar trope that raised practical concerns and individual worries but was not generally linked to religious or moral anxieties in ways that more serious natural occurrences were. Monstrous births and extreme weather conditions needed to be explained by divine intervention, but disability was not counted among these phenomena. ${ }^{60}$ While portrayals of disability remained negative, they were qualified by their frequency and familiarity. As Henri-Jacques Stiker has explained, disability was not a cause for religious fear; instead, it figured in the ethical register of morality and spirituality in a much wider sense, by demonstrating and demanding submission to the divine order. ${ }^{61}$

This is not to say, of course, that we cannot find the early modern understanding of disability problematic. Nor does it mean that disabled people were not discriminated against in the period. But it also was, and is, in the nature of jokes to be distasteful. They break boundaries and question standards of taste and decency. Early modern jokes, too, may represent disability in a hyperbolic fashion that accentuates offensive attitudes just because voicing them was funny, or they may sentimentalize and sanitize what were actually very grim lives. ${ }^{62}$ We have no way of knowing how many of those laughing at disability jokes found them harmless and clean fun, and how many sided with the disabled or questioned the moral stance represented in these jests. Thus it is by no means clear that early modern jests about disability imply a standard social response. But neither is there any reason to doubt that the cruel and repugnant attitudes articulated in the jokes existed. It is easier to believe that disparaging comments about disability are evidence of a cultural rift, a social and political problem that raised different reactions, than to accept them as 


\section{Cultural History}

unquestioned proof that purely insensitive contempt was a standard attitude towards the disabled.

This interpretation can be strengthened if we look at those who thought that laughter was not the correct reaction to encountering disability. Thomas More, for example, famously asserted that in Utopia,

to despise a man for a disfigurement or the loss of a limb is counted as base and disfiguring, not to the man who is laughed at but to him who laughs, for foolishly upbraiding a man with something as if it were a fault which he was powerless to avoid. ${ }^{63}$

Although laughter was born out of the perception of deformity, many humanists thought that laughing at mere physical deformity was cruel. According to Juan Luis Vives, scornful laughter was always inhuman. ${ }^{64}$ The conduct book translator Simon Robson suggested that there were three groups of people who should never be ridiculed: women, those in misery and those who were in any way deformed. ${ }^{65}$ Baldassare Castiglione illustrated the point in The Book of the Courtier. one should not ask a man without a nose where he would fasten his spectacles. ${ }^{66}$

It seems, however, that even though mocking a noseless man was not good behaviour, one could well joke about his spectacles behind his back. Despite the ubiquity of disability in early modern culture, ablebodied society did not regard the place of disability in humour as worthy of special consideration except in face-to-face situations. We might want to consider a somewhat positive explanation for this, one that would take into account humour's transgressive possibilities. Jests often do represent situations where noseless men are asked about their spectacles, as it were. Disabled people are confronted about their disabilities and explicitly mocked. Does this prove only that courtesy writers' advice was needed, because insensitive jokers were inattentive to decorum? Or does it work the other way around, calling attention to the fact that what was presented in jokes was not considered proper behaviour in real life? Jokes were told to shock listeners into laughter, and the laughter raised by disability jokes may have reflected discomfort and disapproval, a recognition of the incorrectness of the sensibilities displayed in the joke.

But laughing in early modern humour was often less of an exercise in intellectual cultural evaluation than an act of simple and speedy gratification. We may be overestimating the laughers' interest in topical analysis if we claim that humour was always a sign 


\section{Disability Humour in English Jestbooks}

of deep cultural uncertainty or conflict of opinion. There is no question that disability also made one laugh through a simple recognition of difference and perhaps an ensuing awareness of superiority.

Garland's interpretation of the social functions of comic disability comes to our assistance here. According to Garland, the cultural functions of disability can be classed into the cohesive, the cathartic and the pathological. ${ }^{67}$ In jestbooks, too, representations of disability support the social and ideological cohesion of the non-disabled majority: images of physical difference draw attention away from other divisions in society and thus help to stabilize social tensions. In a society where anyone could become disabled at any moment, personal tensions about disability also ran high. Laughter at the disabled may be a sign of the fear and embarrassment that otherness provoked. It may alleviate that fear by offering an illusion of mastery over the body and its failings. Questions of power are also obviously embedded in these jokes, since disability can be controlled and the disabled oppressed by creating, through comedy and joking, a discursive context for their disparagement.

Questions and theorizations of disability history have not yet been as central in early modern studies as one would expect. ${ }^{68}$ This is partly because of our imperfect appreciation of the theoretical uses the concept of disability can have and partly because of our imperfect insight into what practical forms and cultural roles disability assumed in the culture of the time. Partly, too, it may be a question of 'blindness' to representations of disability as disability: even though early modern texts abound with disabled characters, without awareness of disability history and its conceptualizations it is possible to screen the issue out of our minds. ${ }^{69}$ Conscious efforts are therefore needed to bring disability and disabled people into historical focus. Early modernists have long been aware that deformities and impairments were of much interest, and of much practical consequence, to the people they study, but the ways in which new disability history formulates its conceptual frames and research tasks gives us the possibility to think again.

A few years ago, Susan Burch and Ian Sutherland asked us historians to consider, with the help of disability history, the question 'who's not yet here? ${ }^{70}$ We knew the disabled were there, in the early modern world, but they were not here, in our books and articles. Disability history, then, seems a promising tool for asking new questions and setting new challenges for early modernists as well. 


\section{Cultural History}

\section{Notes}

1. Ray McDermott and Hervé Varenne, 'Culture as Disability', Anthropology and Education Quarterly, 26:3 (1995), pp. 324-48 (331).

2. Ibid. p. 331.

3. An important question left out of this article is cognitive disability, which is very much present in early modern jokes, especially through the figure of the natural fool. I have discussed fools at length elsewhere; see Anu Korhonen, Fellows of Infinite Jest: The Fool in Renaissance England (Turku: University of Turku, 1999).

4. Tom Shakespeare, 'Joking a Part', Body E Society, 5:4 (1999), pp. 47-52 (48).

5. See, for example, Kim Reid, Edy Hammond Stoughton and Robin M. Smith, 'The Humorous Construction of Disability: "Stand-up" Comedians in the United States', Disability E Society, 21:6 (2006), pp. 629-43; Rebecca Mallett, 'Claiming Comedic Immunity: Or, What Do you Get when you Cross Contemporary British Comedy with Disability', Review of Disability Studies: An International Journal, 64:3 (2010), pp. $5-13$.

6. 'A C Mery Talys' (1526), reprinted in Ian Munro (ed.), 'A Womans Answer is Neuer to Seke': Early Modern Jestbooks, 1526-1635, The Early Modern Englishwoman: A Facsimile Library of Essential Works, Series III: 8 (Aldershot: Ashgate, 2007).

7. Daniel Wickberg, The Senses of Humor: Self and Laughter in Modern America (Ithaca, NY: Cornell University Press, 1998), p. 8; Laurent Joubert, Treatise on Laughter (1579; Tuscaloosa, AL: University of Alabama Press, 1980), pp. 19-26.

8. Rosemarie Garland-Thomson, Extraordinary Bodies: Figuring Physical Disability in American Culture and Literature (New York: Columbia University Press, 1997), p. 6.

9. Ibid. p. 6; Henri-Jacques Stiker, A History of Disability (Ann Arbor: University of Michigan Press, 1999), pp. 69-70.

10. Korhonen, Fellows, pp. 30-45.

11. Marjorie K. McIntosh, 'Networks of Care in Elizabethan Towns: The Example of Hadleigh, Suffolk', in Peregrine Horden and Richard Smith (eds), The Locus of Care: Families, Communities, Institutions, and the Provision of Welfare since Antiquity (London: Routledge, 1998), pp. 71-89 (71-2, 78).

12. For jests on crookedness and lameness, however, see Anthony Copley, Wits Fittes and Fancies (London: Richard Iohnes, 1595), p. 194.

13. Sir Simonds D'Ewes in his autobiography offers us a view into how visual impairments were experienced in practice and how, from the seventeenth century onwards, they were closely linked with reading and writing. Simonds D'Ewes, The Autobiography and Correspondence of Sir Simonds D'Ewes, James Orchard Halliwell (ed.) (London: Richard Bentley, 1845), vol. 1, pp. 4-5.

14. Thomas Twyne, The Schoolemaster (London: Richarde Iohnes, 1583), sig. P3r; Copley, Wits, p. 192.

15. Twyne, Schoolemaster, sig. P3r; John Taylor, Wit and Mirth (London: Henrie Gosson, 1628), sig. B7v; A. S., The Booke of Bulls (London: Daniel Frere, 1636), p. 63; Robert Chamberlain, A New Booke of Mistakes: Or, Bulls with Tales, and Buls without Tales (London: N[icholas] $\mathrm{O}[\mathrm{kes}], 1637)$, p. 228; Hugh Peters, The Tales and Jests of Mr. Hugh Peters (London: S.D., 1660), p. 11; The Complaisant Companion, or, New Jests (London: H.B., 1674), section on 'Forreign Jests' p. 23; William Hickes, CoffeeHouse Jests (London: Hen. Rhodes, 1989), p. 69.

16. For activities in darkness, see Roger A. Ekirch, 'Sleep we Have Lost: Pre-industrial Slumber in the British Isles', The American Historical Review, 106:2 (2001), pp. 343-86 (344, 350). 


\section{Disability Humour in English Jestbooks}

17. Stuart Clark, Vanities of the Eye: Vision in Early Modern European Culture (Oxford: Oxford University Press, 2007), p. 20 and passim.

18. Mirth in Abundance (London: Francis Grove, 1659), p. 10; and see Taylor, Wit and Mirth, sig. B7v; A. S., Booke of Bulls, pp. 20, 28-9; Chamberlain, New Booke, pp. 82-3, $164-5,228$.

19. A. S., Booke of Bulls, p. 20.

20. Simon Dickie, Cruelty and Laughter: Forgotten Comic Literature and the Unsentimental Eighteenth Century (Chicago: University of Chicago Press, 2011), pp. 17-19.

21. Ibid. pp. 17-19; Thomas Hobbes, Leviathan (1651; Aylesbury: Penguin, 1985), p. 25; see also Quentin Skinner, 'Hobbes and the Classical Theory of Laughter', in Tom Sorell and Luc Foisneau (eds), Leviathan after 350 Years (Oxford: Clarendon, 2004), pp. 139-66 (145).

22. Roger Lund, 'Laughing at Cripples: Ridicule, Deformity and the Argument from Design', Eighteenth-Century Studies, 39:1 (2005), pp. 91-114 (p. 111).

23. George Puttenham, The Arte of English Poesie (London: Richard Field, 1589), p. 241.

24. Joubert, Treatise on Laughter, pp. 21-3; see also Baldassare Castiglione, The Book of the Courtier (1561; London: J. M. Dent, 1974), p. 138; Korhonen, Fellows, pp. 119-21.

25. Twyne, Schoolemaster, sig. P3r-P3v.

26. Copley, Wits, p. 94. On the various interweavings of cuckoldry and humour, see also Elizabeth Foyster, 'A Laughing Matter? Marital Discord and Gender Control in Seventeenth-Century England', Rural History, 1:4 (1993), pp. 5-21 (7-9); Laura Gowing, 'Women, Status and the Popular Culture of Dishonour', Transactions of the Royal Historical Society, 6th ser., 6 (1996), pp. 225-34 (p. 162); Bruce Boehrer, Shakespeare among the Animals: Nature and Society in the Drama of Early Modern England (Basingstoke: Palgrave, 2002), pp. 72-7; Bernard Capp, When Gossips Meet: Women, Family, and Neighbourhood in Early Modern England (Oxford: Oxford University Press, 2003), pp. 193-5, 232-3; Pamela Allen Brown, Better a Shrew than a Sheep: Women, Drama, and the Culture of Jest in Early Modern England (Ithaca, NY: Cornell University Press, 2003), pp. 84-5, 89, 115.

27. Chamberlain, New Booke, pp. 164-5.

28. Margaret Cavendish had no intention of accounting for women's loquaciousness in the same way. Margaret Cavendish, The Worlds Olio (London: J. Martin and J. Allestrye, 1655), p. 18.

29. A. S., Booke of Bulls, p. 6.

30. On Bruegel and humour see Walter S. Gibson, Pieter Bruegel and the Art of Laughter (Berkeley: University of California Press, 2006).

31. A. S., Booke of Bulls, section 2: pp. 70-1. In a later version, the beggar is tested by the jokester's stepping on his toes. Complaisant Companion, section on Forreign Jests p. 45 .

32. On comic stereotypes of women's speech, see Linda Woodbridge, Women and the English Renaissance: Literature and the Nature of Womankind, 1540-1620 (Brighton: Harvester, 1984), pp. 207-10; Anthony Fletcher, Gender, Sex and Subordination in England, 1500-1800 (New Haven, CT: Yale University Press, 1995), pp. 14-15, 74; Kathleen Rowe, The Unruly Woman: Gender and the Genres of Laughter (Austin: University of Texas Press, 1995), pp. 38-9; Sara Mendelson and Patricia Crawford, Women in Early Modern England, 1550-1720 (Oxford: Clarendon, 1998), p. 62.

33. Copley, Wits, p. 86. Jokes could also oppose the view that disabled people made bad marriage partners - see Chamberlain, New Booke, pp. 48-9; Complaisant Companion, 


\section{Cultural History}

p. 77 - or side with the disabled partner - see The Letters of Dorothy Osborne to William Temple, G. C. Moore Smith (ed.) (Oxford: Clarendon, 1928), pp. 77-8.

34. 'A C Mery Talys' (1526) and 'Pasquil's Jests: With the Merriments of Mother Bunch' (1635), reprinted in Ian Munro (ed.), 'A Womans Answer is Neuer to Seke': Early Modern Jestbooks, 1526-1635, The Early Modern Englishwoman: A Facsimile Library of Essential Works, Series III: 8 (Aldershot: Ashgate, 2007), fols 17v-18r, sig. A4v; Edward Gosynhyll, Here Begynneth the Schole House of Women (London: John Kyng, 1560), sig. B4v-C1v. The jest was extremely well known; for example Maria Thynne refers to it in a letter to her husband in the early 1610s; see Joan Thynne and Maria Thynne, Two Elizabethan Women: Correspondence of Joan and Maria Thynne 1575-1611, Alison D. Wall (ed.) (Stoke-on-Trent: Wiltshire Record Society, 1983), p. 48.

35. Keith Thomas, 'The Place of Laughter in Tudor and Stuart England', The Times Literary Supplement, 21 January 1977, p. 77.

36. Tim Reinke-Williams, 'Misogyny, Jest-Books and Male Youth Culture in Seventeenth-Century England', Gender Eं History, 21:2 (2009), pp. 324-39.

37. Nicholas Le Strange, Merry Passages and Jeasts: A Manuscript Jestbook of Sir Nicholas Le Strange (1603-1655), Henry Frederick Lippincott (ed.), Salzburg Studies in English Literature 29 (Salzburg: Universität Salzburg, 1974), p. 148.

38. Robert Garland, The Eye of the Beholder: Deformity and Disability in the Graeco-Roman World (London: Duckworth, 1995), p. 74.

39. For an early modern example of linking disability with scatology, see London Jests (London: Dorman Newman, 1684), pp. 166-7.

40. Le Strange recorded the joke twice, giving Mrs Thurlow a name in only one of the versions. He also included a very similar joke told by his father. Le Strange, Merry Passages, pp. 18, 148.

41. A. S., Booke of Bulls, section 2: pp. 83-4.

42. Copley, Wits, pp. 192-3.

43. London Jests, pp. 144-6.

44. Archie Armstrong, A Banquet of Ieasts (London: Richard Royston, 1630), p. 58. For different versions of the joke, see Robert Burton, Versatile Ingenium: The Wittie Companion, or Jests of All Sorts (Amsterdam: Stephen Swart, 1679), p. 125; The Pinder of Wakefield: Being the Merry History of George a Greene the Lusty Pinder of the North (London: G[eorge] P [urslowe] for E. Blackamoore, 1632), sig. F3r. For a different joke with a similar scenario, see London Jests, pp. 166-7.

45. Thomas Lupton, A Thousand Notable Things (London: Iohn Charlewood, 1579), p. 227; Bartholomeus Battus, The Christian Mans Closet (London: Thomas Dawson, 1581), fol. 25v; Desiderius Erasmus of Rotterdam, Seven Dialogues Both Pithie and Profitable (London: Nicholas Ling, 1606), sig. M4v; A Closet for Ladies and Gentlewomen (London: Arthur Johnson, 1608), pp. 163-4.

46. London Jests, pp. 166-7; Hickes, Coffee-House Jests, p. 93. However, there was no attempt in the early modern period to view deafness not as disabling but as constituting a linguistic or cultural community; hence I include it among early modern disabilities. Signing is not mentioned in jestbooks as a possible form of communication, although we know from elsewhere that personal sign languages did exist.

47. Emily Cockayne, 'Experiences of the Deaf in Early Modern England', The Historical Journal, $46: 3$ (2003), pp. 493-510 (503).

48. Ibid. p. 504. 


\section{Disability Humour in English Jestbooks}

49. H. L., Gratiae Ludentes: Iests, from the Vniversitie (London: Tho. Cotes, 1638), pp. $20-1$.

50. Shakespeare, 'Joking a Part', pp. 49-50; Ian Stronach and Julie Allan, 'Joking with Disability: What's the Difference between the Comic and the Tragic in Disability Discourses?', Body Eo Society, 5:4 (1999), pp. 31-45 (34-5).

51. Stronach and Allan, 'Joking', pp. 39-40.

52. Twyne, Schoolemaster, sig. P3r.

53. See, for example, London Jests, p. 184; A. S., Booke of Bulls, p. 37.

54. William M. Hamlin, 'A Lost Translation Found? An Edition of The Skeptick (c. 1590) Based on Extant Manuscripts [with Text]', English Literary Renaissance, 31:1 (2001), pp. 34-51 (50-1).

55. See, for example, Susan Burch and Ian Sutherland, 'Who's Not Yet Here? American Disability History', Radical History Review, 94 (2006), pp. 127-47 (128); Daniel Blackie, Disabled Revolutionary War Veterans and the Construction of Disability in the Early United States, c. 1776-1840 (Helsinki: University of Helsinki, 2010), pp. 20-1.

56. Catherine J. Kudlick, 'History, Power, and Rethinking the Idea of "The Other"', PMLA, 120 (2005), pp. 557-561 (559); Richard Neugebauer, 'Mental Handicap in Medieval and Early Modern England: Criteria, Measurement and Care', in David Wright and Anne Digby (eds), From Idiocy to Mental Deficiency: Historical Perspectives on People with Learning Disabilities (London: Routledge, 1996), pp. 22-43 (25-9).

57. Robert Plot, The Natural History of Stafford-Shire (Oxford: Theater, 1686), p. 300.

58. William Whiteway, William Whiteway of Dorchester: His Diary 1618 to 1635 (Dorchester: Dorset Record Society, 1991), p. 154.

59. John Rous, Diary of John Rous, Incumbent of Santon Downham, Suffolk, from 1625 to 1642, Mary Anne Everett Green (ed.) (London: Camden Society, 1856), pp. 84-5.

60. There are no monstrous births in jestbooks, but for the monstrous as disability, see Kevin Stagg, 'Representing Physical Difference: The Materiality of the Monstrous', in David M. Turner and Kevin Stagg (eds), Social Histories of Disability and Deformity (London: Routledge, 2006), pp. 19-38 (21).

61. Stiker, History of Disability, p. 77.

62. See Dickie, Cruelty and Laughter, p. 40.

63. Thomas More, 'Utopia', The Complete Works of St. Thomas More, vol. 4, Edward Surtz and Jack H. Hexter (eds) (1516-18; New Haven, CT: Yale University Press, 1965), pp. 193.

64. Juan Luis Vives, An Introduction to Wysedome (London: Thomas Berthelet, 1544), sig. I3v-I4r.

65. S[imon] R[obson], The Courte of Ciuill Courtesie (London: Richard Jhones, 1577), pp. 12-13.

66. Castiglione, Book of the Courtier, p. 149; see also Burton, Wittie Companion, pp. 88-9; Dickie, Cruelty and Laughter, p. 18.

67. Garland, Eye of the Beholder, p. 74.

68. As Daniel Blackie observes, disability history has so far, with some notable exceptions, been concentrating mainly on the last 150 years of Western history: Blackie, Disabled Revolutionary War Veterans, p. 24.

69. This problem has been discussed, for example, in David T. Mitchell and Sharon L. Snyder, Narrative Prosthesis: Disability and the Dependencies of Discourse (Ann Arbor: University of Michigan Press, 2000), pp. 51-2.

70. Burch and Sutherland, 'Who's Not Yet Here', p. 143. 